\title{
Asthma attacks in children are always preceded by poor asthma control: myth or maxim?
}

Asthma is the most common chronic disease in childhood, with a substantial burden on the healthcare system globally [1]. Asthma symptoms can be broken down into two separate domains, asthma control (day-to-day asthma symptoms such as cough or wheeze at night or with activity) and asthma attacks (significant intermittent worsening of asthma, often secondary to a trigger of some sort). A joint American Thoracic Society/European Respiratory Society task force characterised asthma attacks as a change from the patient's previous status, with moderate asthma attacks defined as "events that are troublesome to the patient, and that prompt a need for a change in treatment, but that are not severe. These events are clinically identified by being outside the patient's usual range of day-to-day asthma variation." Severe attacks were defined as "events that require urgent action on the part of the patient and physician to prevent a serious outcome, such as hospitalization or death from asthma." [2]. Some attack definitions include the use of systemic corticosteroids for treatment $[3,4]$, while other definitions include declines in lung function as a part of the definition $[5,6]$. Importantly, patients may not use the terminology of "attack," but rather may call such events attacks or flare-ups [5].

Asthma attacks are a major source of both morbidity and mortality in children with asthma $[7,8]$. Asthma attacks in children may be associated with decreased lung function over time [9, 10]. In addition, asthma attacks are a significant source of healthcare-related costs [11], particularly when emergency visits or hospitalisations are required [12]. Therefore, asthma attacks are a marker for interventions targeted at decreasing many negative asthma-related outcomes.

Asthma control is a second domain of illness that is also related to substantial morbidity. The Global Initiative for Asthma defines asthma control as "the extent to which the manifestations of asthma can be observed in the patient, or have been reduced or removed by treatment" [5]. It is typically comprised of two domains: symptom control (impairment domain) and risk of future attacks (risk domain) $[5,13]$. For the purposes of this article, our use of the term asthma "control" will pertain to the impairment domain, or symptom frequency, intensity and functional limitations [14].

It seems a foregone conclusion that children with poor asthma control, including worsened day-to-day symptoms, would be at higher risk for an asthma attack. However, the remainder of this article will seek to evaluate the evidence for the question: are asthma attacks in children preceded by a period of poor asthma control?

\section{Predictors of asthma attacks}

First, we will evaluate some of the known predictors of asthma attacks outside of asthma control. There are a wide range of potential predictors of asthma attacks, from demographic and historical risk factors to lung function, biomarker data and genetics (table 1) [16].
Cite as: De Keyser $\mathrm{HH}$, Szefler S. Asthma attacks in children are always preceded by poor asthma control: myth or maxim? Breathe 2020; 16 : 200169. 
Table 1 Predictors of asthma exacerbations

\begin{tabular}{|c|c|c|c|c|}
\hline Demographic & History & Lung function & Biomarkers & Environmental \\
\hline $\begin{array}{l}\text { Children/young } \\
\text { children }\end{array}$ & Previous exacerbation(s) & $\begin{array}{l}\text { Spirometry: } \mathrm{FEV}_{1}, \mathrm{FEV}_{1} / \mathrm{FVC} \text {, } \\
\mathrm{FEF}_{25-75}\end{array}$ & $\begin{array}{l}\text { Eosinophils: peripheral } \\
\text { blood, sputum }\end{array}$ & $\begin{array}{l}\text { Indoor allergens with } \\
\text { sensitisation }\end{array}$ \\
\hline Women & Poor asthma control & Bronchodilator response & $\begin{array}{l}\text { Number of } \\
\text { inhalant allergen } \\
\text { sensitisations }\end{array}$ & $\begin{array}{l}\text { Outdoor allergens } \\
\text { with sensitisation }\end{array}$ \\
\hline $\begin{array}{l}\text { Economically } \\
\text { disadvantaged }\end{array}$ & $\begin{array}{l}\text { Difficult-to-control } \\
\text { asthma }\end{array}$ & Impulse oscillometry & & $\begin{array}{l}\text { Smoking/smoke } \\
\text { exposure status }\end{array}$ \\
\hline Overweight & $\begin{array}{l}\text { Poor controller } \\
\text { medication adherence }\end{array}$ & & & \\
\hline
\end{tabular}

$\mathrm{FEF}_{25-75}$ : forced expiratory flow at $25-75 \%$ of FVC; $\mathrm{FEV}_{1}$ : forced expiratory volume in $1 \mathrm{~s}$; FVC: forced vital capacity; SABA: short-acting $\beta$-agonist. Reproduced from [15], with permission from the publisher.

\section{Demographics}

Younger age in children has been associated with an increased risk of asthma attack [17, 18], as has obesity [19]. African American and Puerto Rican race/ethnicity has been associated with a moderately increased risk of asthma attacks and emergency department visits [17, 19, 20], and this effect in African American individuals persists in some studies when controlling for poverty, healthcare provision, area of residence and level of parental education [17, 20]. However, an evaluation of readmission rates in African American children found that $80 \%$ of their increased risk could be explained after balancing biological, environmental, disease management, access to care, and socioeconomic factors, indicating that the increased risk is likely multifactorial [21]. Another study found that black children were more likely to be admitted to the emergency department for their asthma; however, statistical balancing for social variables negated this increased risk [22]. Thus, the question of the impact of race/ethnicity on asthma attacks is a complex one, and probably affected by many more factors than genetics alone. Finally, behavioural factors such as poor adherence to asthma medications may increase attack risk [23, 24].

\section{A recent asthma attack}

Perhaps the best studied and most robust predictor of an asthma attack in children is a history of a recent attack [25-31]. A systematic review of attack predictors in 5-12-year-old children found the strongest odds ratios for future attacks (2.0 to 4.1$)$ in those who had a previous asthma attack [17].

\section{Lung function}

Decreased $\mathrm{FEV}_{1} / \mathrm{FVC}$ ratio has been associated with increased risk of asthma attacks [28, 32], and FEV $<80 \%$ predicted may be associated with emergency room use, particularly in black children [20].

\section{Biomarkers}

There is some evidence that biomarkers, such as elevated serum IgE $[18,28]$ and eosinophils [18, 28 ], are associated with an increased risk of an attack. Additionally, having multiple allergic triggers for asthma may increase attack risk [26, 28].

\section{Environmental factors}

Poor access to care has been associated with increased risk of asthma attacks across multiple studies [17]. Environmental tobacco smoke may mildly increase the risk of attacks in children [17, $19,33]$. In addition, airborne pollutants including ozone and particulate matter may be a driver of attacks, especially when combined with viral and allergic exposures [19, 33-35].

\section{Poor asthma control does not always precede an attack}

Asthma attacks can and do occur in children with apparent good asthma control and no recent history of an attack [16]. A large electronic health records study including more than 51000 adults with asthma found that of those characterised as frequent exacerbators, $58 \%$ had mild/moderate asthma [36]. Symptom tracking in a study of 285 children with asthma found a poor positive predictive value of worsening of asthma symptoms 
for an attack [29]. Changes in impulse oscillometry detected peripheral airway obstruction in 4-7-yearold patients even during asymptomatic periods, and such obstruction was associated with an increased chance of an asthma attack [37]. Children who are admitted to the intensive care unit with severe attacks may experience a more rapid onset of attack symptoms than controls [38]. A secondary data analysis of the Childhood Asthma Management Program (CAMP) showed that while having persistent asthma symptoms was predictive of an attack, the predictors of poor asthma control were different than the predictors of an attack [39]. However, uncontrolled asthma at baseline certainly does not guarantee that a child will have an asthma attack [32], and asthma severity may not be associated with attack risk especially in younger age groups [40]. There may in fact be a group of children with attack prone asthma that may be a distinct clinical phenotype [41].

Viral infections are one of the most important triggers of asthma attacks in children [33, 42, 43], and importantly, it is a trigger that is not entirely predictable. Multiple factors may increase the risk of viral induced attacks, including an interplay between genetics, atopy and infection type $[42,44]$. In addition to acute viral infections, a predominance of certain bacteria may predispose to asthma attacks, although the role of acute bacterial infection in asthma attacks remains unclear [45]. One adult study showed that asthmatic adults were susceptible to attacks related to infection, irrespective of level of asthma control [46]. Attacks in children follow a seasonal pattern of prevalence, with increased attack rates particularly in the autumn season [18, 47, 48], which may reflect a confluence of atopy and viral infections during that time of the year.

Poor perception of actual level of control may account for some lack of association between asthma control and attacks. Perception of asthmarelated symptoms relies on a complex interplay of activation of neural pathways, transmission of information and interpretation and understanding of that information by the patient, complicated further by acknowledgement of that information by the parent or caregiver of the patient in young children [49]. There have been documented discrepancies between both parental and provider assessment of asthma control and more objective measures [50-53], and children, especially those with severe asthma, may be particularly vulnerable to poor perception [54]. One small study found that nearly $50 \%$ of children studied were unable to detect either acute obstruction or bronchodilation [55], and symptom perception may be worse in younger children [55]. Increased levels of airway inflammation may be associated with poor perception of symptoms as well, possibly due to sensory receptor destruction [54]. Dyspnoea related to obesity may cause discrepancy in the perception of asthma control as well [56].

\section{Self-evaluation questions}

1 Which of the following is the most robust predictor of a future asthma exacerbation in children?
a) serum total lgE
b) history of a previous exacerbation
c) exposure to tobacco smoke
d) decreased $\mathrm{FEV}_{1} / \mathrm{FVC}$ ratio

2 True or false: children with mild asthma are not at risk from fatal asthma exacerbations.

3 Which of the following seasons have been shown to be the highest risk for exacerbations in children?
a) Spring
b) Summer
c) Autumn
d) Winter

4 True or false: poor day-to-day control of asthma symptoms accounts for the biggest source of asthma healthcare-related costs in children.

Perhaps one of the most concerning features of asthma attacks is the fact that fatal asthma attacks can occur at any level of asthma severity. One study of adult and child asthma deaths in Australia showed that $34 \%$ of fatal asthma victims had no significant limitation due to asthma prior to their fatal attack, and 39\% had never been admitted to the hospital prior to that event [57]. When evaluating the subset of children under 20 years of age in this group, 33\% had a history of mild or "trivial" asthma, and only $36 \%$ had severe asthma [58]. An evaluation of Danish children showed that children who died from asthma were more likely to be in the 15-19-year-old age group, and had few asthma symptoms and poor asthma follow-up [59].

\section{Poor asthma control does precede an attack}

Various studies have demonstrated an increased risk of asthma attack in those with poorly controlled asthma [26, 60]. A meta-analysis of 68 studies in children showed a moderately increased risk of asthma attacks (OR of 1.4 and 7.8 in various studies) in children with persistent symptoms/ poor control [17]. The TENOR study, which enrolled 4756 asthmatic adults, adolescents and children, found that asthma control both as measured by validated questionnaires or by US national guideline classifications were associated with increased risk of future asthma attacks [25]. Very poorly controlled asthma may pose a higher attack risk than not well controlled asthma [61]. Increased use of rescue medications has also been associated with increased attack risk [62, 63].

Multiple composite risk scores have been developed in an attempt to predict asthma attacks, and many include some measure of asthma control as one factor. One such score 


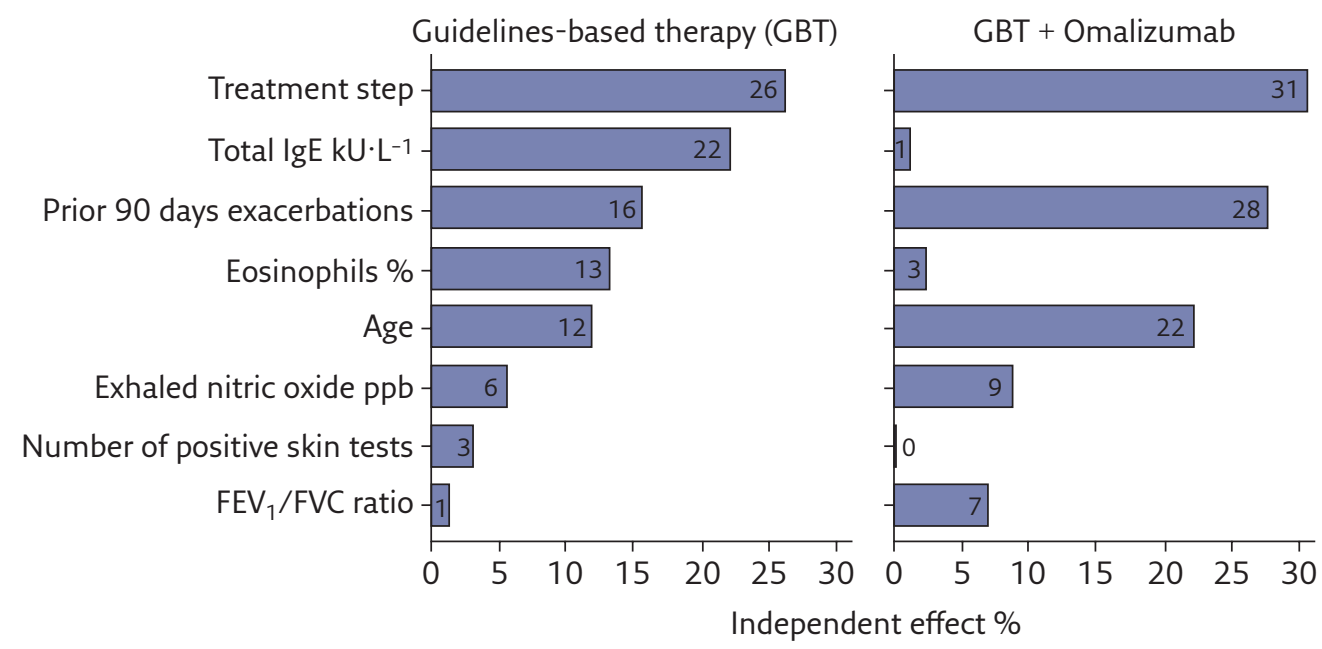

Figure 1 Relative importance of index variables for predicting exacerbations during the intervention period. Bar length represents the independent percentage of contribution of the variable in explaining exacerbations. The numbers at the end of each bar represent the independent effect of each variable. Reproduced from [18], with permission from the publisher.

was validated in the CAMP cohort and in a group of Costa Rican children and included multiple measures of asthma control including daily symptoms and exercise intolerance, and was validated for predicting risk of attacks [64]. The Seasonal Asthma Attack Predictive Index (saEPI) was developed to predict risk of asthma attack in children by season [18, 28], and included a treatment step which could be considered a proxy for asthma severity (i.e. a higher treatment step needed to control symptoms may indicate worsened overall severity). In a validation analysis, treatment step was the most relatively important factor in predicting attacks in children treated with guidelines-based therapy and those treated with guidelines-based therapy plus omalizumab to prevent fall attacks (figure 1) [18].

\section{Overall opinion}

Poor control of asthma is a marker of increased asthma-related inflammation, and is one of many possible predictors of asthma attacks. For many patients, poor asthma control does precede an asthma attack. However, there are also cases in which asthma control may be (or may be perceived to be) good prior to an asthma attack. Viral or atopic triggers may trigger attacks in those who are well controlled and poorly controlled alike, and unfortunately, having well controlled or mild asthma does not protect children from fatal asthma attacks. Therefore, while there is truth to the statement that poor control may often precede an asthma attack, the statement that the perception of poor asthma control always precedes an asthma attack is an overstatement.

\title{
Key points
}

- A previous asthma attack is the best predictor of another attack.

- Poor asthma control is often, but not always, associated with an asthma attack.

- Asthma attacks, even fatal attacks, can happen in children with well controlled or mild asthma.

\author{
Affiliations \\ Heather H. De Keyser, Stanley Szefler \\ University of Colorado School of Medicine; Children's Hospital Colorado, Breathing Institute, Aurora, CO, USA.
}

\section{Conflict of interest:}

H.H. De Keyser reports consulting fees from AstraZeneca and a donation of research devices from Propeller Health outside the submitted work. S. Szefler reports acting as a consultant for development and oversight of paediatric studies to meet regulatory requirements for new medications and oversight of a global study of this new medication as well as assistance in manuscript development (approximately $\$ 5000$ received over past 3 years, funds to his university) for Boehringer-Ingelheim, participation in two Pediatric Asthma Summit meetings to discuss asthma management worldwide (received approximately $\$ 4000$ for this work) and in two global advisory meetings for drug development including children (received approximately $\$ 4000$ for this work as well, all funds 
to his university) for GlaxoSmithKline, assistance in educating investigators regarding severe asthma in children and also for guidance in new product development (approximately $\$ 12000$ over the past 3 years, funds to his university) for AstraZeneca, acting as a consultant for new drug development for childhood asthma (approximately $\$ 4000$ paid to his university in the past year) for Sanofi, acting as a consultant for new drug development for childhood asthma (approximately $\$ 2500$ paid to his university in the past year) for Regeneron, grant support from Propeller Health, and discussion of research data regarding electronic monitoring of adherence and rescue therapy and potential future research studies (approximately $\$ 5000$ paid to his university over the past 2 years) with Propeller Health, outside the submitted work.

\section{References}

1. Ferrante G, La Grutta S. The burden of pediatric asthma. Front Pediatr 2018; 6: 186

2. Reddel HK, Taylor DR, Bateman ED, et al. An official American Thoracic Society/European Respiratory Society statement: asthma control and exacerbations: standardizing endpoints for clinical asthma trials and clinical practice. Am J Respir Crit Care Med 2009; 180: 59-99.

3. National Asthma Education and Prevention Program. Expert Panel Report 3 (EPR-3): Guidelines for the Diagnosis and Management of Asthma-Summary Report 2007. J Allergy Clin Immunol 2007; 120: S94-138.

4. Fuhlbrigge A, Peden D, Apter AJ, et al. Asthma outcomes: exacerbations. J Allergy Clin Immunol 2012; 129: S34-S48.

5. Global Initiative for Asthma. Global Strategy for Asthma Management and Prevention, 2019. Available from: www. ginasthma.org

6. Bousquet J, Mantzouranis E, Cruz AA, et al. Uniform definition of asthma severity, control, and exacerbations: document presented for the World Health Organization Consultation on Severe Asthma. J Allergy Clin Immunol 2010; 126: 926-938.

7. Bush A, Griffiths $C$. Improving treatment of asthma attacks in children. BMJ 2017; 359: j5763.

8. Custovic A, Johnston SL, Pavord I, et al. EAACl position statement on asthma exacerbations and severe asthma. Allergy 2013; 68: 1520-1531

9. O'Brian AL, Lemanske RF Jr, Evans MD, et al. Recurrent severe exacerbations in early life and reduced lung function at school age. J Allergy Clin Immunol 2012; 129: 1162-1164.

10. O'Byrne PM, Pedersen S, Lamm CJ, et al. Severe exacerbations and decline in lung function in asthma. $\mathrm{Am} J$ Respir Crit Care Med 2009; 179: 19-24.

11. Fu LS, Tsai MC. Asthma exacerbation in children: a practical review. Pediatr Neonatol 2014; 55: 83-91.

12. Lane S, Molina J, Plusa T. An international observational prospective study to determine the cost of asthma exacerbations (COAX). Respir Med 2006; 100: 434-450.

13. National Heart, Lung, and Blood Institute. National Asthma Education and Prevention Program Expert Panel Report 3: Guidelines for the Diagnosis and Management of Asthma: Full Report 2007. Available from: www.nhlbi.nih.gov/ health-pro/guidelines/current/asthma-guidelines/full-report

14. Haselkorn T, Fish JE, Zeiger RS, et al. Consistently very poorly controlled asthma, as defined by the impairment domain of the Expert Panel Report 3 guidelines, increases risk for future severe asthma exacerbations in The Epidemiology and Natural History of Asthma: Outcomes and Treatment Regimens (TENOR) study. J Allergy Clin Immunol 2009; 124: 895-902 e1-4.

15. Hoch H, Liu AH. Chapter 12: predicting and preventing asthma exacerbations. In: Szefler SJ, Holguin F, Wechsler ME, eds. Personalizing Asthma Management for the Clinician. Elsevier, 2018, pp. 129-141.

16. Forno E, Celedon JC. Predicting asthma exacerbations in children. Curr Opin Pulm Med 2012; 18: 63-69.

17. Buelo A, McLean S, Julious $S$, et al. At-risk children with asthma (ARC): a systematic review. Thorax 2018; 73: 813-824.

18. Hoch HE, Calatroni A, West JB, et al. Can we predict fall asthma exacerbations? Validation of the seasonal asthma exacerbation index. J Allergy Clin Immunol 2017; 140: 1130-1137.

19. Puranik S, Forno E, Bush A, et al. Predicting severe asthma exacerbations in children. Am J Respir Crit Care Med 2017; 195: 854-859.
20. Franklin JM, Grunwell JR, Bruce AC, et al. Predictors of emergency department use in children with persistent asthma in metropolitan Atlanta, Georgia. Ann Allergy Asthma Immunol 2017; 119: 129-136.

21. Beck AF, Huang B, Auger KA, et al. Explaining racial disparities in child asthma readmission using a causal inference approach. JAMA Pediatr 2016; 170: 695-703.

22. Fitzpatrick AM, Gillespie SE, Mauger DT, et al. Racial disparities in asthma-related health care use in the National Heart, Lung, and Blood Institute's Severe Asthma Research Program. J Allergy Clin Immunol 2019; 143: 2052-2061.

23. Engelkes M, Janssens HM, de Jongste JC, et al. Medication adherence and the risk of severe asthma exacerbations: a systematic review. Eur RespirJ 2015; 45: 396-407.

24. Williams LK, Peterson EL, Wells K, et al. Quantifying the proportion of severe asthma exacerbations attributable to inhaled corticosteroid nonadherence. J Allergy Clin Immunol 2011; 128: 1185-1191.

25. Chipps BE, Zeiger RS, Dorenbaum A, et al. Assessment of asthma control and asthma exacerbations in the epidemiology and natural history of asthma: outcomes and treatment regimens (TENOR) observational cohort. Curr Respir Care Rep 2012; 1: 259-269.

26. Haselkorn T, Zeiger RS, Chipps BE, et al. Recent asthma exacerbations predict future exacerbations in children with severe or difficult-to-treat asthma. J Allergy Clin Immunol 2009; 124: 921-927.

27. Miller MK, Lee JH, Miller DP, et al. Recent asthma exacerbations: a key predictor of future exacerbations. Respir Med 2007; 101: 481-489.

28. Teach SJ, Gergen PJ, Szefler SJ, et al. Seasonal risk factors for asthma exacerbations among inner-city children. J Allergy Clin Immunol 2015; 135: 1465-1473.

29. Covar RA, Szefler SJ, Zeiger RS, et al. Factors associated with asthma exacerbations during a long-term clinical trial of controller medications in children. J Allergy Clin Immunol 2008; 122: 741-747.

30. DiMango E, Rogers L, Reibman J, et al. Risk factors for asthma exacerbation and treatment failure in adults and adolescents with well-controlled asthma during continuation and step-down therapy. Ann Am Thorac Soc 2018; 15: 955-961.

31. Colice G, Chisholm A, Dima AL, et al. Performance of database-derived severe exacerbations and asthma control measures in asthma: responsiveness and predictive utility in a UK primary care database with linked questionnaire data. Pragmat Obs Res 2018; 9: 29-42.

32. Quezada W, Kwak ES, Reibman J, et al. Predictors of asthma exacerbation among patients with poorly controlled asthma despite inhaled corticosteroid treatment. Ann Allergy Asthma Immunol 2016; 116: 112-117.

33. Guibas GV, Makris M, Papadopoulos NG. Acute asthma exacerbations in childhood: risk factors, prevention and treatment. Expert Rev Respir Med 2012; 6: 629-638.

34. Kim J, Kim H, Kweon J. Hourly differences in air pollution on the risk of asthma exacerbation. Environ Pollut 2015; 203: 15-21.

35. Tosca MA, Ruffoni S, Canonica GW, et al. Asthma exacerbation in children: relationship among pollens, weather, and air pollution. Allergol Immunopathol 2014; 42: 362-368.

36. Bloom Cl, Palmer T, Feary J, et al. Exacerbation patterns in adults with asthma in England. A population-based study. Am J Respir Crit Care Med 2019; 199: 446-453.

\section{Suggested answers}

1.b.

2. False.

3. c.

4. False. 
37. Schulze J, Biedebach S, Christmann M, et al. Impulse oscillometry as a predictor of asthma exacerbations in young children. Respiration 2016; 91: 107-114

38. Sala KA, Carroll CL, Tang YS, et al. Factors associated with the development of severe asthma exacerbations in children. J Asthma 2011; 48: 558-564.

39. Wu AC, Tantisira K, Li L, et al. Predictors of symptoms are different from predictors of severe exacerbations from asthma in children. Chest 2011; 140: 100-107.

40. Galant SP, Morphew T, Amaro S, et al. Current asthma guidelines may not identify young children who have experienced significant morbidity. Pediatrics 2006; 117: 1038-1045.

41. Deliu M, Yavuz TS, Sperrin M, et al. Features of asthma which provide meaningful insights for understanding the disease heterogeneity. Clin Exp Allergy 2018; 48: 39-47.

42. Jackson DJ, Sykes A, Mallia P, et al. Asthma exacerbations: origin, effect, and prevention. J Allergy Clin Immunol 2011; 128: 1165-1174.

43. Costa LD, Costa PS, Camargos PA. Exacerbation of asthma and airway infection: is the virus the villain? J Pediatr (Rio J) 2014; 90: 542-555.

44. Kim CK, Callaway Z, Gern JE. Viral infections and associated factors that promote acute exacerbations of asthma. Allergy Asthma Immunol Res 2018; 10: 12-17.

45. Saglani S, Custovic A. Childhood asthma: advances using machine learning and mechanistic studies. Am J Respir Crit Care Med 2019; 199: 414-422.

46. Reddel H, Ware S, Marks G, et al. Differences between asthma exacerbations and poor asthma control. Lancet 1999; 353: 364-369.

47. Sears MR. Epidemiology of asthma exacerbations. J Allergy Clin Immunol 2008; 122: 662-668.

48. Larsen K, Zhu J, Feldman LY, et al. The annual september peak in asthma exacerbation rates. Still a reality? Ann Am Thorac Soc 2016; 13: 231-239.

49. Banzett RB, Dempsey JA, O’Donnell DE, et al. Symptom perception and respiratory sensation in asthma. Am J Respir Crit Care Med 2000; 162: 1178-1182.

50. Hammer SC, Robroeks CM, van Rij C, et al. Actual asthma control in a paediatric outpatient clinic population: do patients perceive their actual level of control? Pediatr Allergy Immunol 2008; 19: 626-633.

51. Carroll WD, Wildhaber J, Brand PL. Parent misperception of control in childhood/adolescent asthma: the Room to Breathe survey. Eur Respir J 2012; 39: 90-96.
52. Shefer G, Donchin M, Manor O, et al. Disparities in assessments of asthma control between children, parents, and physicians. Pediatr Pulmonol 2014; 49: 943-951.

53. Rhee H, Belyea MJ, Elward KS. Patterns of asthma control perception in adolescents: associations with psychosocial functioning. J Asthma 2008; 45: 600-606.

54. Barnes PJ, Szefler SJ, Reddel HK, et al. Symptoms and perception of airway obstruction in asthmatic patients: Clinical implications for use of reliever medications. J Allergy Clin Immunol 2019; 144: 1180-1186.

55. Baker RR, Mishoe SC, Zaitoun FH, et al. Poor perception of airway obstruction in children with asthma. J Asthma 2000; 37: 613-624.

56. Sah PK, Gerald Teague W, Demuth KA, et al. Poor asthma control in obese children may be overestimated because of enhanced perception of dyspnea. J Allergy Clin Immunol Pract 2013; 1: 39-45.

57. Robertson CF, Rubinfeld AR, Bowes G. Deaths from asthma in Victoria: a 12-month survey. Med J Aust 1990; 152 511-517.

58. Robertson CF, Rubinfeld AR, Bowes G. Pediatric asthma deaths in Victoria: the mild are at risk. Pediatr Pulmonol 1992; 13: $95-100$

59. Jørgensen IM, Jensen VB, Bülow $S$, et al. Asthma mortality in the Danish child population: risk factors and causes of asthma death. Pediatr Pulmonol 2003; 36 : 142-147.

60. Robroeks CM, van Vliet D, Jobsis $Q$, et al. Prediction of asthma exacerbations in children: results of a one-year prospective study. Clin Exp Allergy 2012; 42: 792-798.

61. Calhoun WJ, Haselkorn T, Mink DR, et al. Clinical burden and predictors of asthma exacerbations in patients on guideline-based steps 4-6 asthma therapy in the TENOR cohort. J Allergy Clin Immunol Pract 2014; 2: 193-200.

62. Andrews $\mathrm{AL}$, Brinton $\mathrm{DL}$, Simpson $\mathrm{KN}$, et al A Longitudinal Examination of the Asthma Medication Ratio in Children with Medicaid. J Asthma 2020; 57: 1083-1091.

63. Makhinova T, Barner JC, Richards KM, et al. Asthma controller medication adherence, risk of exacerbation, and use of rescue agents among texas medicaid patients with persistent asthma. J Manag Care Spec Pharm 2015; 21: 1124-1132.

64. Forno E, Fuhlbrigge A, Soto-Quiros ME, et al. Risk factors and predictive clinical scores for asthma exacerbations in childhood. Chest 2010; 138: 1156-1165. 